\title{
Identifying the Drawbacks of the Problem-Solving Skills by Using a Three-Tier Diagnostic Test with Google Form Assistant
}

\author{
Inarsih Meutia $^{1, *}{ }^{*}$ Deka Maulidiansyah ${ }^{1,}$ Edi Istiyono ${ }^{2}$ \\ ${ }^{1}$ Master of Physics Education, Faculty of Mathematics and Natural Sciences, Universitas Negeri Yogyakarta, \\ Indonesia \\ ${ }^{2}$ Department of Educational Research and Evaluation, Graduate School, Universitas Negeri Yogyakarta, \\ Indonesia \\ *Corresponding author. Email: inarsihmeutia.2019@student.uny.ac.id
}

\begin{abstract}
The present scientific paper aimed to identify of problem-solving skills and students' responses to the use of google form as a media for a three-tier diagnostic test in the tenth-grade students at Senior High School (SMA) of Indonesia Islamic University (UII) of Yogyakarta. The weaknesses of problem-solving skills using three-tier diagnostic test questions assisted by google form on the materials of work and energy lessons. The questions employed had been valid and reliable. The research method used was descriptive qualitative. The subjects of this study were 26 tenth-grade students who were randomly selected. The results showed that the problem-solving skills of students were in the moderate category. Students utilized the google form to identify drawbacks in problem-solving skills employing a three-level diagnostic test, including the very high category.
\end{abstract}

Keywords: Problem-solving, Three-tier diagnostic test, Google form, Work and energy

\section{INTRODUCTION}

Education has an important role in the process of improving human resources [1]. The role can be seen from the condition that humans are changing over time. This also applies to the process of educational development which has to keep up with the times. The times have brought challenges to education. The challenges of education in the era of the industrial revolution 4.0 have to be able to prepare students to face the challenges of a dynamic world. Facing these challenges students should have self-competence to be able to compete. One of the competencies that should be possessed is problem-solving skills.

Problem-solving is included in the category of higher-order thinking skills [2]. When coping with the student's problems, it would think about the process and how to solve the problem [3]. One of the subjects in its implementation requiring problem-solving skills in physics. This is in line with the 2013 curriculum which required students to have problem-solving skills [4]. Therefore, it can be said that problem-solving skills are important to be owned and developed by students. The problem-solving skills possessed by students can influence the mind-set when solving problems in real life.

Assessment using a diagnostic test can measure the level of understanding and skills of students [5]. The diagnostic test can also provide information about misunderstandings and how students think. The results of the diagnostic test can be used as an evaluation of learning [6]. The existence of learning evaluation is expected to help overcome learning difficulties and improve students' thinking skills.

Furthermore, the form of questions employed in the diagnostic test is in the form of multiple-choice questions with a level of confidence or what is commonly called a three-tier diagnostic test. Also, the use of three-tier diagnostic tests is more effective than one-tier and two-tier diagnostic tests. Besides, the three-tier diagnostic test can provide an overview of students' understanding and misunderstanding of concepts [7], [8]. This is because in the three-tier diagnostic test there is a choice of the confidence level that can identify students' lack of understanding [9]. 
However, the use of three-tier diagnostic tests to identify students' problem-solving skills has not been widely used.

In the industrial revolution 4.0 era, the development in educational assessment has changed rapidly, especially in the fields of education and technology. One of the alterations that occurred in the assessment using the Paper and Pencil Test (PPT) began to be replaced by an assessment called the Computer Based Test (CBT) [10]. The use of CBT allows flexibility, paperless, saving time, and making it easier to assess [11]. Additionally, the CBT system in the assessment let it easier to find out the skills and to provide feedback to students after an assessment is conducted [12], [13]. The reasons lead to the benefits of CBT assessment more effective and efficient.

During the outbreak of Covid-19 globally, the majority of schools in Indonesia should implement an online system. The assessment of employing the CBT system during the Covid-19 pandemic was effective. One of the CBT media that can be used is the google form. This is due to the use of google form which is online and free [14].

The google form can contain a large number of questions so that it can be used for three-tier diagnostic tests. The test results using google form can be found quickly, making it easier to assess. Therefore, the use of google form as an assessment medium can attract the attention of students so that it can motivate them to learn independently [15], [16].

The current paper discussed the use of a three-tier diagnostic test to identify the problem-solving skills of students with google form assistant. It was recommended that the test be carried out online because it is more effective and efficient. Students can also take the test from home in which the pandemic that requires it to be at home so that social distancing sustains.

\section{RESEARCH METHOD}

The research was quantitative descriptive. The instrument employed was a test named a three-tier diagnostic test which was validated and reliable. The instrument consisted of 8 three-tier or three-tier multiple-choice questions of three-tier assisted by the google form application.

Then, the instrument was validated by experts. After obtaining the research results, it was calculated using the Aiken's V formula to determine its validity value. The following equations are used:
$V=\frac{\sum s}{[n-(c-1)]}$

Where $s=r-l_{o}, l_{o}$ was the number of the lowest validity assessment (in this case 1), $c$ seemed the highest validity rank (in this case 3 ), $r$ was the number given by the validator, $n$ showed the number of validators, and $V$ was the Aiken's V score. Aiken's V score was then categorized based on Table 1 .

Table 1. Product Criteria

\begin{tabular}{|l|l|}
\hline Percentage (\%) & Category \\
\hline $80 \leq x \leq 100$ & Very Good \\
\hline $60 \leq x<80$ & Good \\
\hline $40 \leq x<60$ & Moderate \\
\hline $20 \leq x<40$ & Low \\
\hline
\end{tabular}

The results obtained were then converted into percentages. The percentage of problem-solving skills using the equation:

$\bar{X}=\frac{\sum X}{n} \times 100 \%$

In which $\bar{X}$ was the percentage score, $\Sigma X$ was the score obtained, and $\mathrm{n}$ was the maximum score. The results of the percentage analysis of students' problemsolving skills were then categorized based on Table 2 [17].

Table 2. Assessment Categories

\begin{tabular}{|l|l|}
\hline Percentage (\%) & Category \\
\hline $80 \leq x \leq 100$ & Very Good \\
\hline $60 \leq x<80$ & Good \\
\hline $40 \leq x<60$ & Moderate \\
\hline $20 \leq x<40$ & Low \\
\hline $0 \leq x<20$ & Very Low \\
\hline
\end{tabular}

The student response questionnaire consisted of nine criteria. The percentage of total score in each item response data of students was gained by using the equation:

$P=\frac{\sum X}{\sum X_{i}} \times 100 \%$

Where $\mathrm{P}$ was the percentage of the score, $\Sigma \mathrm{X}$ was the total score for each item, $\Sigma X_{i}$ was the ideal score. The percentage of the total response data of students was calculated by using the equation: 


$$
P_{\text {total }}=\frac{\sum P}{n}
$$

Then, $\mathrm{P}_{\text {total }}$ was the percentage of total responses, $\Sigma \mathrm{P}$ was the number of percentages of the score, and $\mathrm{n}$ was the number of items or statements. Percentage results were categorized based on Table 3 [18].

Table 3. The Percentage of Students' response result

\begin{tabular}{|l|l|}
\hline Result Percentage Range (\%) & Category \\
\hline $80 \leq x \leq 100$ & Very Good \\
\hline $60 \leq x<80$ & Good \\
\hline $40 \leq x<60$ & Moderate \\
\hline $20 \leq x<40$ & Low \\
\hline $0 \leq x<20$ & Very Low \\
\hline
\end{tabular}

\section{RESULT AND DISCUSSION}

\subsection{Result}

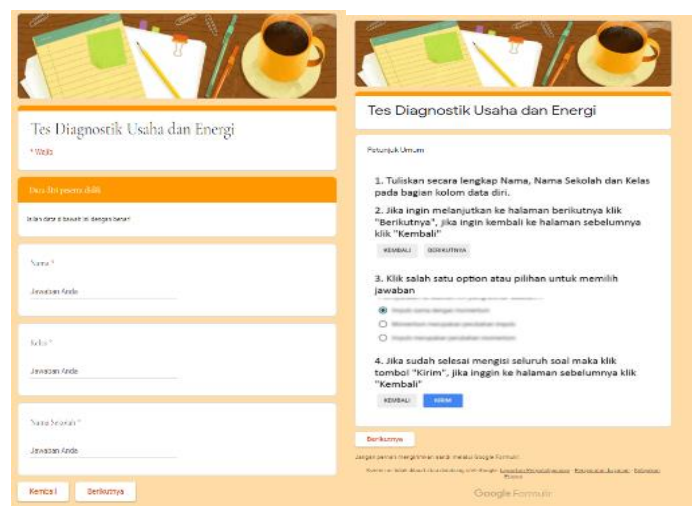

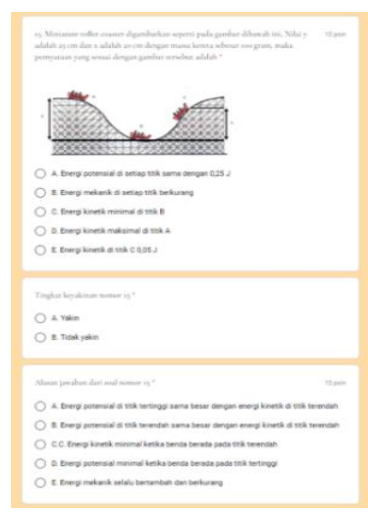

Figure 2 The form three-tier diagnostic test questions on google form

This study uses google form as a medium for giving questions as shown in Figure 1 and three-tier diagnostic test questions as shown in Figure 2. Data analysis on students' problem-solving skills on optical instrument can be seen in Table 4. The results of students' responses to google form media as a threetier diagnostic test media are in Table 5.

\subsection{Discussion}

The identification of problem-solving skills in this research was conducted at SMA UII Yogyakarta in the tenth-grade students employing a three-tier diagnostic test with google form Assistant. The three-tier diagnostic test used has been validated and the results are valid. The reliability score of the three-tier diagnostic test was 0.64 in the high category [19].

Figure 1 Google form

Table 4. The result of analysis of problem-solving skills

\begin{tabular}{|c|c|c|c|}
\hline Aspects & Indicators & $\begin{array}{l}\text { The percentage of } \\
\text { Students' Answer }\end{array}$ & Categories \\
\hline \multirow[t]{2}{*}{ Identification } & $\begin{array}{l}\text { Distinguishing between irrelevant information and } \\
\text { relevant information }\end{array}$ & $52,88 \%$ & Moderate \\
\hline & $\begin{array}{l}\text { Identifying the information falling into the issue } \\
\text { interpretation }\end{array}$ & $50,48 \%$ & Moderate \\
\hline \multirow[t]{2}{*}{ Plan } & Giving the logical reason from a suggestion offered & $55,29 \%$ & Moderate \\
\hline & $\begin{array}{l}\text { Initiate a variety of strategies that may be in } \\
\text { progress }\end{array}$ & $42,31 \%$ & Moderate \\
\hline \multirow[t]{2}{*}{ Implementation } & Solving multi-representation problems & $39,42 \%$ & Low \\
\hline & $\begin{array}{l}\text { Analyzing the information available for } \\
\text { interpretation }\end{array}$ & $49,04 \%$ & Moderate \\
\hline
\end{tabular}




\begin{tabular}{|l|l|l|l|}
\hline Evaluation & $\begin{array}{l}\text { Re-examining the effectiveness of the problem- } \\
\text { solving process }\end{array}$ & $54,33 \%$ & Moderate \\
\cline { 2 - 4 } & Criticizing the solution result in conclusions & $54,33 \%$ & Moderate \\
\hline
\end{tabular}

Table 5. Results of students' responses to google form

\begin{tabular}{|c|l|l|}
\hline No & Categories & Score Percentages \\
\hline 1 & The test display with google form is interesting & $92,75 \%$ \\
\hline 2 & The image in the test with google form seems to be clear & $95,65 \%$ \\
\hline 3 & The image in the test with google form is understandable & $91,30 \%$ \\
\hline 4 & The language used in the test with google form is easy to understand & $84,78 \%$ \\
\hline 5 & $\begin{array}{l}\text { The material in the test using google form is following the work and energy instrument } \\
\text { theme }\end{array}$ & $95,65 \%$ \\
\hline 6 & Test with google form is easily accessible & $92,03 \%$ \\
\hline 7 & The test with google form is practical to use & $92,03 \%$ \\
\hline 8 & The general instructions for using the test using google form are displayed & $90,58 \%$ \\
\hline 9 & $\begin{array}{l}\text { The test with google form can help find out skills and weaknesses in the mastery of } \\
\text { work and energy }\end{array}$ & $92,75 \%$ \\
\hline
\end{tabular}

As shown in Table 4, it shows the results of data analysis of problem-solving skills employing a threetier diagnostic test assisted by google form on the materials of work and energy lessons. Each aspect of problem-solving skills consists of two indicators. The identification aspect of the first indicator obtained $52.88 \%$ in the moderate category. This indicates that students can distinguish objects that have large and small work with information in the form of data and images. The second indicator is $50.48 \%$ in the moderate category. This means that students can identify and interpret information related to kinetic energy experiments. The results of the identification aspect show that several students are able to define problems in the questions given.

The aspect of the plan on problem-solving skills, the first indicator was $55.29 \%$ with moderate category. It showed that students can provide reasons for solutions related to formulating the height of an object. The second indicator was $42.31 \%$ in the moderate category. This indicated that students can think of the right solution in terms of the difference in kinetic energy at a certain height. The results of the aspect of the plan showed that several students can plan strategies in solving problems faced.

In the implementation aspect of the problemsolving skills, the first indicator got a percentage of $39.42 \%$ with a low category. This showed the skills of students in multi-representation when applying existing data information to the solution equation associated with kinetic energy and potential energy was still lacking. It was due to the fact that students were only limited to entering known values in the equation without analyzing the problems they faced [20].

The second indicator obtained $49.04 \%$ with a moderate category. It indicated that students can analyze and interpret the information provided to determine ball speed. The results in this aspect of implementation showed that some students have not been able to solve problems in a multi-representation manner, but can cope with and interpret the issues.

In the evaluation aspect of problem-solving skills, the first indicator was $54.33 \%$ included in the moderate category. It can define that students are able to re-check the conformity of the statement with the information provided. The second indicator obtained $54.33 \%$ with moderate category. This meant that students can conclude statements with the information provided. The results of the evaluation aspect showed that some students can examine and criticize the emerging problems.

Furthermore, the students' problem-solving skills on the materials of work and energy lessons were classified as moderate category with an overall average of $49.76 \%$, so it can be concluded that the use of a three-tier diagnostic test was able to identify students' problem-solving skills. Assessment employing a three-tier diagnostic test can identify students' understanding [21]. The problem-solving 
skills of students was quite influenced by several factors, including the learning methods used by the teacher, the facilities and learning resources utilized, as well as the motivation and readiness of students in the learning process. The display of the three-tier diagnostic test with google form media to identify weaknesses in student problem-solving skills can be seen as in Figure 1. Validation of google form media using Aiken's V score with a score of 1 . This shows that the use of google form is very good for use as a medium of computer-based assessment.

The results of the student's questionnaire responses to the use of google form media can be seen in Table 5 . The total score percentage shows that $91.95 \%$ is in the very high category, this means that students can work on three-tier diagnostic test questions easily using google form. This is because the use of google classroom is easy to access for students [22].

\section{CONCLUSION}

To sum up, the problem-solving skills of the tenth grade in Senior High School of Indonesia Islamic University (SMA UII) of Yogyakarta are in the category of moderate in the material of work and energy. The response of students to the use of google form to identify problem-solving skills using the threetier diagnostic test was very high. Therefore, problemsolving skills can be identified using a three-tier diagnostic test assisted by google form.

\section{REFERENCES}

[1] I.D. Martyaningrum, D.N. Rachmani, Wuryanto, The Enhancement of Students' Ability in Problem Solving and Mathematical Disposition Aspect Through Brain-Based Learning Model, Unnes Journal of Mathematics Education 7(1) (2018) 31-38. DOI: https://doi.org/10.15294/ujme.v7i1.21854

[2] R.E. Slavin, Educational Psychology: Theory and Practice, Pearson, 2018.

[3] E. Ersoy, Problem Solving and Its Teaching in Mathematics, Online Journal New Horizons Education 6(2) (2016) 79-87.

[4] Ministry of Education and Culture, Regulation of the Minister of Education and Culture No. 21 of 2016 concerning Standard Content of 2013 Curriculum, Jakarta, 2016.

[5] R.M.D. Guido, R.A.B. Dela Cruz, Physics Diagnostic Test: An Approach to Qualify Astronomy Students, International Letters of
Social and Humanistic Sciences 63 (2015) 129135.

DOI: https://doi.org/10.18052/www.scipress.com/ilshs .63 .129

[6] R. Diani, J. Alfin, Y.M. Anggraeni, M. Mustari, D. Fujiani, Four-Tier Diagnostic Test with Certainty of Response Index on the Concepts of Fluid, in: Journal of Physics: Conference Series, vol. 1155, IOP Publishing, Bristol, 2019, pp. 110. DOI: https://doi.org/10.1088/17426596/1155/1/012078

[7] I. Caleon, R. Subramaniam, Development and Application of A Three-Tier Diagnostic Test to Assess Secondary Students' Understanding of Waves, International Journal of Science Education 32(7) (2010) 939-961. DOI: https://doi.org/10.1080/09500690902890130

[8] D.K. Gurel, A. Eryilmaz, L.C. McDermott, A Review and Comparison of Diagnostic Instruments of Identify Students' Misconceptions in Science, Eurasia Journal of Mathematics, Science and Technology Education 11 (5) (2015) 989-1008.

DOI: https://doi.org/10.12973/eurasia.2015.1369a

[9] D. Gurcay, E. Gulbas, Development of ThreeTier Heat, Temperature and Internal Energy Diagnostic Test, Research in Science and Technological Education, 33(2) (2015) 197-217. DOI:

https://doi.org/10.1080/02635143.2015.1018154

[10] E. Istiyono, Computer adaptive test as the appropriate model to assess physics achievement in 21st century, in: Advances in Social Science, Education and Humanities Research, vol. 178, Atlantis Press, Amsterdam, 2019, pp. 304-309. DOI: https://doi.org/10.2991/icoie-18.2019.67

[11] E. Istiyono, W.S.B. Dwandaru, A.K. Permatasari, Aristiawan, Developing computer based test to assess students' problem-solving in physics learning, in: Journal of Physics: Conference Series, vol. 1440, IOP Publishing, Bristol, 2020, pp. 1-9. DOI: https://doi.org/10.1088/1742$\underline{6596 / 1440 / 1 / 012060}$

[12] C. Redecker, Ø. Johannessen, Changing Assessment - Towards A New Assessment Paradigm Using ICT, European Journal of Education 48(1) (2013) 79-96. DOI: https://doi.org/10.1111/ejed.12018 
[13] B.B. Riley, A.C. Carle, Comparison of Two Bayesian Methods to Detect Mode Effects Between Paper-Based and Computerized Adaptive Assessments: A Preliminary Monte Carlo Study, BMC Medical Research Methodology 12(1) (2012). DOI: https://doi.org/10.1186/1471-2288-12-124

[14] M. Djenno, G.M. Insua, A. Pho, From Paper to Pixels: Using Google Forms for Collaboration and Assessment, Library Hi Tech News 32(4) (2015) 9-13. DOI: https://doi.org/10.1108/LHTN-12-2014-0105

[15] B. Agung, S. Syaefulloh, I.M. Ridwan, A.M.H. Mamun, D. Sumpena, Q.Y. Zakiah, Google formbased learning assessment, in: Advances in Social Science, Education and Humanities Research, vol. 253, Atlantis Press, Amsterdam, 2019, pp. 529-531. DOI: https://doi.org/10.2991/aes-18.2019.118

[16] T. Kato, Y. Kambayashi, Practice for SelfRegulatory Learning Using Google Forms: Report and Perspectives, Information Engineering Express International Institute of Applied Informatics, 2(4) (2016) 11-20.

[17] E.P. Widyoko, Technique for Developing Research Instruments. Pustaka Pelajar, 2013.

[18] Riduwan, Thesis Preparation Methods and Techniques. Alfabeta, 2010.

[19] A.T. Astuti, Supahar, Mundilarto, E. Istiyono, Development of assessment instruments to measure problem solving skills in senior high school, in: Journal of Physics: Conference Series, vol. 1440, IOP Publishing, Bristol, 2020, pp. 1-9. DOI: $\quad$ https://doi.org/10.1088/1742$\underline{6596 / 1440 / 1 / 012063}$

[20] A.M.R. Tumanggor, Supahar, H. Kuswanto, E.S. Ringo, Using four-tier diagnostic test instruments to detect physics teacher candidates' misconceptions: Case of mechanical wave concepts, in: Journal of Physics: Conference Series, vol. 1440, IOP Publishing, Bristol, 2020, p. 012059. DOI: https://doi.org/10.1088/1742$\underline{6596 / 1440 / 1 / 012059}$

[21] E. Taslidere, Development and Use of A ThreeTier Diagnostic Test to Assess High School Students' Misconceptions about The Photoelectric Effect, Research in Science and Technological Education 34(2) (2016) 164-186.
DOI:

https://doi.org/10.1080/02635143.2015.1124409

[22] M. Iqbal, J. Simarmata, F Feriyansyah, A.R.S. Tambunan, O. Sihite, A. Gandamana, G.N. Eza, F. Kurniawan, A Asiah, F. Rozi, F Faisal, I.F.U. Manurung, M. Ihwani, P.L.A. Nathan, N. Sitanggang, N. Simbolon, E.B. Simanjuntak, T. Limbong, Using Google Form for Student Worksheet as Learning Media, International Journal of Engineering and Technology 7(3.4) (2018) 321-324.

DOI: https://doi.org/10.14419/ijet.v7i2.29.13646 